\title{
Simulation of Electricity Generation from Biogas for Ugandan Rural Community
}

\author{
Aldo Okullo*, Noah Tibasiima, Joshua Barasa \\ Department of Chemistry, Kyambogo University, Kampala, Uganda \\ Email address: \\ okulloapita@yahoo.com(A. Okullo),ntibasiima@gmail.com (N. Tibasiima),brsjosh@gmail.com (J. Barasa) \\ ${ }^{*}$ Corresponding author
}

To cite this article:

Aldo Okullo, Noah Tibasiima, Joshua Barasa. Simulation of Electricity Generation from Biogas for Ugandan Rural Community. American Journal of Chemical Engineering. Vol. 6, No. 3, 2018, pp. 37-43. doi: 10.11648/j.ajche.20180603.11

Received: August 3, 2017; Accepted: August 24, 2017; Published: June 29, 2018

\begin{abstract}
One of Uganda's greatest hindrances to development is lack of access to energy. In rural areas where about $84 \%$ of the population lives, access to electricity is less than $2 \%$ a situation that lives rural communities to continue depending on biomass based fuels in forms of firewood and charcoal. This paper proposes the utilization of biogas to generate off-grid electricity for the rural community. A simulation of electricity generation from biogas for Ugandan rural community using Aspen HYSYS V8.8 for computational modeling was developed on thermodynamic concepts. Two systems were considered; a gas-turbine (GT) only system and a GT-with steam turbine (ST) in the bottom cycle, based on $71 \%$ methane - $29 \%$ carbon dioxide as inlet biogas composition. The results obtained showed that it is possible to obtain $2.5 \mathrm{MW}$ of electricity using a gas turbine (GT) only system and an additional 1MW when a combined cycle system (GT-ST) is considered. An analysis of the exhaust gases showed that there are negligible amounts of gaseous pollutant though not in amounts that could constitute environmental threats when disposed to the atmosphere. In order to meet the system's need, a cattle head count of 13740 is estimated to be maintained for a daily supply of 670 tons of cow manure.
\end{abstract}

Keywords: Biogas, Biomass, Power Generation, Simulation

\section{Introduction}

Uganda is blessed with abundant natural resources that are fairly distributed throughout the country; the fertile land, the minerals and the diverse flora and fauna resources. Most of these resources are renewable in nature and have the potential, if fully exploited, to provide for the energy demand of a 36.6 million population (mid 2016) growing at about $3 \%$ annually [1]. However with a poverty rate at $19.7 \%$ [1] among many other factors, these resources are underutilized leaving the landlocked East African nation among the poor countries in Africa with a per capita energy consumption estimated at 39 $\mathrm{kg}$ oil equivalent ( $\mathrm{kgOE}$ ) compared to Kenya's $80 \mathrm{kgOE}$ and Italy at $2959 \mathrm{kgOE}$ [2]. One of Uganda's greatest hindrances to development is lack of access to energy and this keeps the nation in a vicious cycle of poverty since access to energy is a driving force to eliminate poverty [3, 4]. About $90 \%$ of the country's energy matrix is dominated by biomass based sources portioned into firewood $(78.6 \%)$, charcoal $(5.6 \%)$ and crop residues $(4.7 \%)$. These are used for cooking and water heating in rural areas, most urban households, institutions, and commercial buildings. Currently, charcoal consumption in Uganda is estimated at 580,000 tons per annum with a biomass equivalent of about 6 million tons of wood, based on the conversion efficiency of $10 \%$ for the charcoal stoves in use. The per capita consumption of firewood in rural and urban areas is $680 \mathrm{~kg} / \mathrm{yr}$ and $240 \mathrm{~kg} / \mathrm{yr}$ respectively. Per capita charcoal consumption is $4 \mathrm{~kg}$ and $120 \mathrm{~kg}$ in rural and urban areas respectively [5], charcoal being a commodity for sale to the urban from the rural communities. Electricity contributes only $1.4 \%$ to the national energy balance while petroleum products, which are mainly used for vehicles and thermal power plants, account for the remaining 9.7\% [5].

The country is currently in the development of her 6.5 billion barrel of oil fields and the establishment of a 60,000 bpsd refinery to supplement its energy requirements. A planned $100 \mathrm{MW}$ natural gas fired thermal power station is also in the pipeline. Power generation for urban industries is heavily dependent on fossil fuel consumption whereas rural industries 
depend on biomass utilization. However as fossil fuel depletion will become a reality later in future and the destruction to the environment due to deforestation, soil erosion and greenhouse gas (GHG) emissions, the country has no option but to start looking into ways of exploiting renewable resources of energy.

Electricity is critical for Uganda to drive her economy in order to attain the growth trajectory and socio-economic transformations she needs. However, the installed electricity power plant capacity is only at $895.5 \mathrm{MW}$ of which $20.4 \%$ is for household supply and this is still very low [1] compared to Kenya's 36\% [6] and yet ironically Kenya imports 30MW from Uganda.

In rural areas where about $84 \%$ of the population lives, access to electricity is less than $2 \%[2,7]$ mainly due to the prohibitive cost of connecting remote and isolated areas to the national grid [5]. The national grid is supplied majorly by hydro-power $(82 \%)$ and thermal $(10 \%)$ with mini-hydro at $(5 \%)$, and cogeneration (3\%) [8]. The situation is worsened by the lengthy drought, inadequate investment in low cost generation capacity and a relatively high load growth.

To alleviate this problem, a search into the utilization of decentralized off-grid renewable energy systems to support Uganda in meeting its SE4All targets by 2030 has been initiated by the government through the Renewable Energy Policy 2007 (REP-2007). The goal is to increase, in significant proportions, the contribution of Renewable Energy to the energy matrix from $4 \%$ to $61 \%$ by the year 2017 however this is currently only at about $52 \%$. The government has set out various strategies to improve energy access to the rural population through the Rural Electrification Agency (REA) mandated to increase rural electricity access to $22 \%$ by 2022 , up from the current rate of $2 \%$.

The use of biogas in electricity generation has been advocated for by many researchers [9-11]. Though solid biomass is the major source of energy in rural Uganda, production of biogas, an energy carrier derived from biomass, has quickly been gaining ground with the government targeting to install 100,000 bio-digesters based on cattle manure by 2017 [2]. Agriculture is the backbone of Uganda's economy and approximately $80 \%$ of the households in Uganda are involved in agricultural practices comprising of $75.4 \%$ crop growing, $57.6 \%$ livestock farming and $66.9 \%$ mixed farming [1]. A single household especially in the Western and South Western rural regions of Uganda can own as many as 800 heads of well-bred cattle since number in cattle is a sign of prestige in this part of the nation. It is evident from the stats above that as agricultural operations become gradually consolidated, the generation of wastes from these practices presents an immense opportunity for these communities to obtain feedstock for biogas production which can be used in power plant systems for electricity generation as off-grid stations, especially for such rural areas.

Okello et al. [12] conducted a study on the bioenergy potential of agricultural and forest residues in Uganda. As can be observed in figure 1, the authors indicated that the crop residue energy potential was about $150 \mathrm{PJ}^{-1}$ and the energy potential of animal manure (human manure inclusive) amounted to about 65PJ $\mathrm{y}^{-1}$. Manure from the 11.7 million heads of cattle (as of 2008) contributed an energy potential of about 45 $\mathrm{PJ} \mathrm{y}^{-1}$ whereas human manure contributed 2.69PJ $\mathrm{y}^{-1}$, each with a $0.2 \mathrm{~m}^{3} / \mathrm{kg}$ biochemical potential. The results were in conformity with the government's policy to install biodigesters to harness this potential. However in order to utilize biogas for electricity generation, infrastructure that utilizes the produced digester gas has to be developed and implemented nationwide.

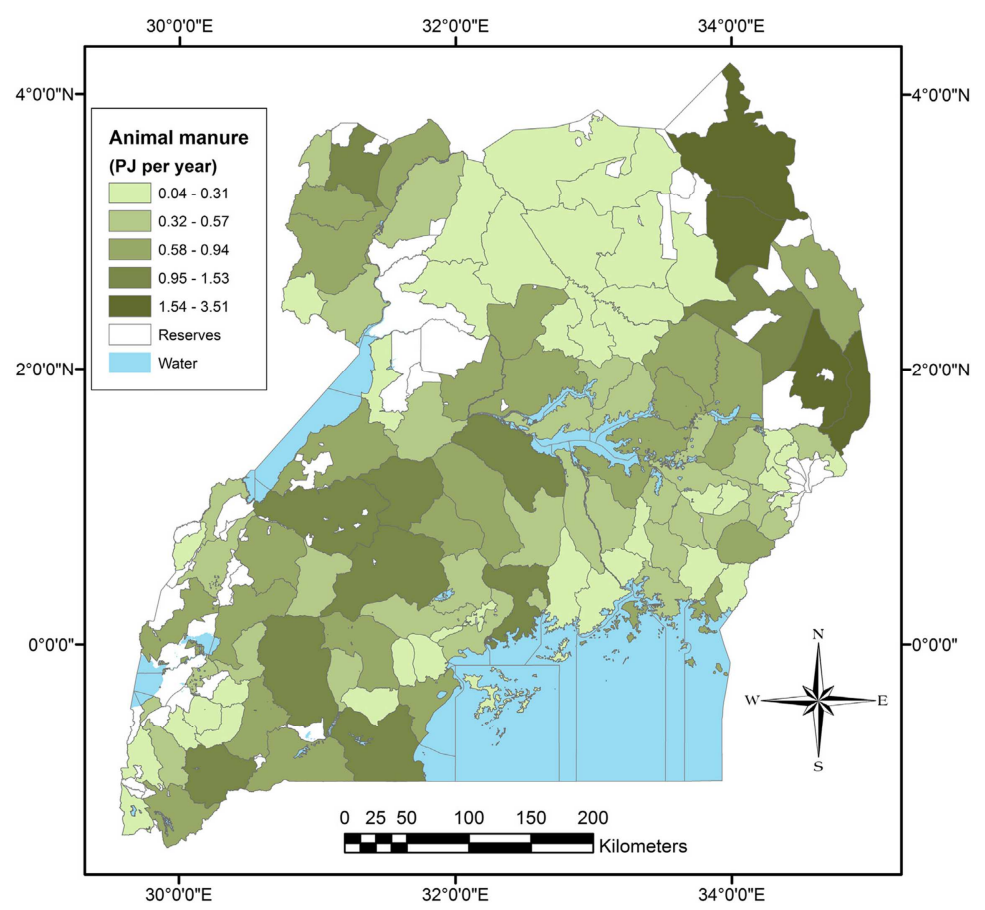

Figure 1. Animal manure energy potential distribution in Uganda. Source [12]. 
Apart from need to develop infrastructure, most limitations to the exploitation of biogas in power generation are attributed to the composition and nature of the biogas. Biogas is a low calorific value fuel (at about $21.5 \mathrm{MJ} / \mathrm{m}^{3}$ ) compared to natural gas $\left(36 \mathrm{MJ} / \mathrm{m}^{3}\right)$. This is due to the presence of noncombustible impurities in the biogas.

In their study, Rasi et al. [13] analyzed the composition of biogas from a sewage treatment plant digester, landfill and a farm biogas plant in order to assess the potential use of biogas for bioenergy. The authors found that biogas components vary with different plants; carbon dioxide content ranges from $36 \%$ to $41 \%$, methane from $48 \%$ to $65 \%$, nitrogen from $1 \%$ to $17 \%$, and oxygen is less than $1 \%$. Sewage digester biogas contains the highest methane content; landfill biogas contains the lowest methane and the highest nitrogen contents in winter. The total volatile organic compounds (TVOCs) range from 5 to $268 \mathrm{mg} / \mathrm{m}^{3}$, and the farm biogas plant has the lowest TVOCs. Sulphur compounds are found in all three cases. As such biogas should be purified before injection into the natural gas grid for electricity generation [14] and to increase its calorific value by removal of acidic gases and other impurities. This process, also known as methane $\left(\mathrm{CH}_{4}\right)$ enrichment includes the separation of carbon dioxide $\left(\mathrm{CO}_{2}\right)$ from biogas $[15,16]$. Purification based on $\mathrm{CO}_{2}$ removal can be accomplished through cryogenic separation.

Membrane separation, organic physical scrubbing, chemical scrubbing, pressure swing adsorption, and high pressure water scrubbing [16]. The above techniques are discussed in detail in the SGC's report 270 [17]. However, since biogas upgrading is expensive, direct combustion is proposed for power generation when sufficient quantity of the gas is available [9].

Among several techniques implemented in biogas-based electricity generation are the gas turbine (Brayton cycle), reciprocating internal combustion engine (Otto cycle), Combined Cycle power plants, Stirling cycle engine and fuel cells [18]. The low capital cost to power ratio of gas turbines (GTs) as well as high reliability without complexity, easy commissioning and commercial operation, high flexibility and very short time for start-up and running make GTs more suitable for electricity generation [9, 19].

In particular, digester gas is suitable for small gas turbines raging from tens of kilowatts to several megawatts because the amount of the gas produced at a single source is usually limited [20]. Unfortunately this technology has not been exploited in Uganda due to lack of experience and technological knowhow. Reference [21] reported that biogas has been variously applied for heating and/or electricity generation purposes all over the world with the authors stating that albeit biogas-based power generation is at an experimental stage in the UK, it already accounted for around $0.5 \%$ of the total output power. In the US, biogas fuels account for about $1 \%$ of power generation, while obtaining a climate-change benefit equivalent to a decrease in $\mathrm{CO}_{2}$ emissions in the electricity sector by more than $10 \%$.
A 1.4MW combined cycle biogas plant was simulated by [9] using MATLAB to obtain the plant's thermal design parameters. The authors gave a comprehensive report on the thermodynamic performance of the micro-power system that used GT cycle and Organic Rankine Cycle (ORC) as the top and bottoming cycles respectively. This work showed support for application in power generation systems.

Huang and Crookes [22] simulated biogas by diluting natural gas with varying fractions of $\mathrm{CO}_{2}$ from $0 \%$ to about $40 \%$ and used it in a single cylinder spark ignition engine as fuel. The authors established that increasing the fraction of $\mathrm{CO}_{2}$ in biogas can lower $\mathrm{NOx}$ emissions and enable the compression ratio to be increased. However, the cylinder pressure is reduced, resulting in the simultaneously reductions of power and thermal efficiencies and the increase of unburned hydrocarbon emissions.

$\mathrm{Ga}$ et al. [23] developed a hybrid biogas-petroleum conversion kit for a station engine that consumed $1 \mathrm{~m}^{3}$ of biogas to produce $1 \mathrm{kWh}$ of electricity. Compared to petroleum, the cost for the production of $1 \mathrm{kWh}$ of electricity by biogas could save 0.7 US $\$$ and could lead to a reduction of $1 \mathrm{~kg}$ of $\mathrm{CO}_{2}$ emission.

A comparative economic analysis of gas turbine-based power generation and combined heat and power systems using biogas fuel was conducted by [10]. The authors simulated a 5 MW-class gas turbine fueled with biogas and concluded that a combined cycle system could supply $22 \%$ more electricity than the gas turbine-only system with $13 \%$ shorter payback period and 34\% larger total NPV than the gas turbine-only case.

In this work, simulations for biogas electricity generation as off-grid power stations in Uganda's cattle rich rural communities is conducted basing on thermodynamic concepts. This is in line with the government policy of Rural Electrification and the SDGs.

\section{Materials and Methods}

The methods used in this work involved data collection and analysis of the characteristics describing human population, number of heads of cattle and the need for electricity as determined by $[1,5]$. Given the nature of the biogas commonly collected, two systems for power generation are used in the simulation; a gas-turbine (GT) only system and a GT-with steam turbine (ST) in the bottom cycle system were considered. Aspen HYSYS V8.8 was used for computational modeling. Since biogas is composed mainly of methane and carbon dioxide, it was assumed that trace components of accompanying other gases were negligible and the performance using biogas purity of $71 \%$ methane and $29 \%$ carbon dioxide were analyzed.

\subsection{Process Simulation}

Albeit some differences do exist between results obtained from process simulation and real plant process operations, modern simulation software, if effectively used, can provide 
dependable information on process operation due to their comprehensive thermodynamic packages, advanced calculation techniques and vast component libraries. The case that was considered is shown in Table 1. When using HYSYS, design parameters from [9, 10] were used. The utilized system simulation and assessment was developed basing on the following assumptions:

(a). Energy storage and transport delay in all unit Ops are negligible thus steady state operation is applicable.

(b). Combustion of the fuel is $100 \%$ complete.

(c). From heuristics, combustion air mixture is considered ideal with composition of oxygen, nitrogen, carbon dioxide and water vapor as $0.2059,0.7748$, and 0.0003 and 0.019 respectively.

(d). Compressor and turbines are adiabatic

The Peng-Robinson and ASME steam thermodynamic packages were specified for the operation of the topping and bottoming cycles following the decision algorithm outlined by [24].

Table 1. Biogas Properties.

\begin{tabular}{ll}
\hline Gas Properties & Values \\
\hline $\mathrm{CH}_{4}(\mathrm{Vol} \%)$ & 71 \\
$\mathrm{CO}_{2}(\mathrm{Vol} \%)$ & 29 \\
$\mathrm{LHV}(\mathrm{kJ} / \mathrm{kmol})$ & 569919.13 \\
\hline
\end{tabular}

Table 2. Design Parameters used in the simulation model.

\begin{tabular}{lll}
\hline System part & Parameter & $\begin{array}{l}\text { Design } \\
\text { Value }\end{array}$ \\
\hline Gas Turbine & Compressor Isentropic Efficiency & $85 \%$ \\
& Pressure ratio & 10 \\
& Combustion chamber inlet temperature & $335^{\circ} \mathrm{C}$ \\
& Turbine Isentropic efficiency & 85 \\
& Turbine inlet temperature & $1050^{\circ} \mathrm{C}$ \\
Steam Turbine & Inlet water temperature & $20^{\circ} \mathrm{C}$ \\
& Inlet water pressure & $10 \mathrm{bar}$ \\
& Steam temperature & $180^{\circ} \mathrm{C}$ \\
& Steam Pressure & $9.8 \mathrm{bar}$ \\
& Turbine isentropic efficiency & $85 \%$ \\
\hline
\end{tabular}

The procedure followed in determining the efficiency for each case is presented in equations (1)-(3)

$$
\begin{aligned}
\eta & =\left(\frac{P_{\text {net }}}{E_{\text {input }}}\right) \times 100 \\
E_{\text {input }} & =(\dot{m} \times L H V)_{\text {biogas fuel }} \\
P_{\text {net }} & =P_{G T}+P_{S T}-P_{\text {aux }}
\end{aligned}
$$

Where $\eta$ is the overall efficiency of the system in consideration, $E_{\text {input }}$ is the energy input of the fuel, $P_{\text {net }}$ is the net power output of the system, $P_{G T}, P_{S T}$ are the gas turbine and steam turbine power outputs and $P_{a u x}$ is the auxiliary power consumption in pumps and compressors.

The determination of the number of cattle required for a particular power output and digester volume was based on the equations outlined by [25] on $0.1 \mathrm{~kg}$ of cow manure as a basis to generate power of $0.008973 \mathrm{kWh}$.

$$
\dot{m}_{\text {manure }}=\left(\frac{\phi}{0.008973}\right) \times 0.1
$$

Where $\dot{m}_{\text {manure }}$ is the flow-rate of cow manure $(\mathrm{kg} / \mathrm{day})$ fed to the digester, $\phi$ is the electricity energy to be generated $(\mathrm{kWh} /$ day).

The rate of water to dilute the manure is calculated based on the good ratio of manure and water in biogas process 1:1 as such:

$$
\dot{m}_{\text {water }}=\dot{m}_{\text {manure }}
$$

The total feeding rate to the digester $\dot{m}_{\text {total }}$ is the sum of the water and manure flow rates. The volumetric rate of the material feeding $\left(\mathrm{m}^{3} /\right.$ day) is calculated by dividing the total feeding rate by the density of the slurry $\left(\rho \mathrm{kg} / \mathrm{m}^{3}\right)$ as;

$$
F=\left(\frac{\dot{m}_{\text {total }}}{\rho}\right)
$$

Thus the digester volume is determined from

$$
V_{\text {digester }}=\tau(\alpha+1) F
$$

Where $\tau$ is the minimum retention time (10-15days) of material to make anaerobic microorganisms grow well without washout and $\alpha$ is a factor of safety.

Manure production was based on a typical fully grown $700 \mathrm{~kg}$ Ankole-Watusi cattle breed which can produce as much as $50 \mathrm{~kg}$ of manure per day [26].

\subsection{System Configuration}

A GT-only system and combined cycle GT-ST system are considered in this study. The GT-only system (Figure 3 ) was developed basing on the Brayton cycle wherein both expansion and compression occurred in same rotating movers. The system consists of three main components; the combustion chamber $(\mathrm{G})$, compressor, and turbine-generator. Air is drawn in by the compressor and delivered to the combustion chamber. Biogas is fed to the combustion chamber as fuel where it is assumed to burn to completion. The produced flue gases are then passed to a turbine, where they expand and transfer energy to the turbine. The turbine propels the compressor on one hand to compress the incoming gas and the generator on the other hand to produce power. The turbine is controlled by regulating the biogas flow into the combustion chamber. In the combined cycle GT-ST system (Figure 4), the gases from the combustion chamber are fed to the gas turbine (GT) as before to generate (GT) power. The waste exhaust gases from the top cycle are captured by a heat recovery steam generator (HRSG) made of an economizer, super heater and evaporator. The HRSG heats water in a boiler to supply steam to the bottoming cycle which is based on the steam Rankine model. The steam expands in the bottom turbine to produce electricity (STpower). Products from this bottom condensate turbine are fed into a condenser, and the water output is pressurized by a pump and sent to the HRSG. 


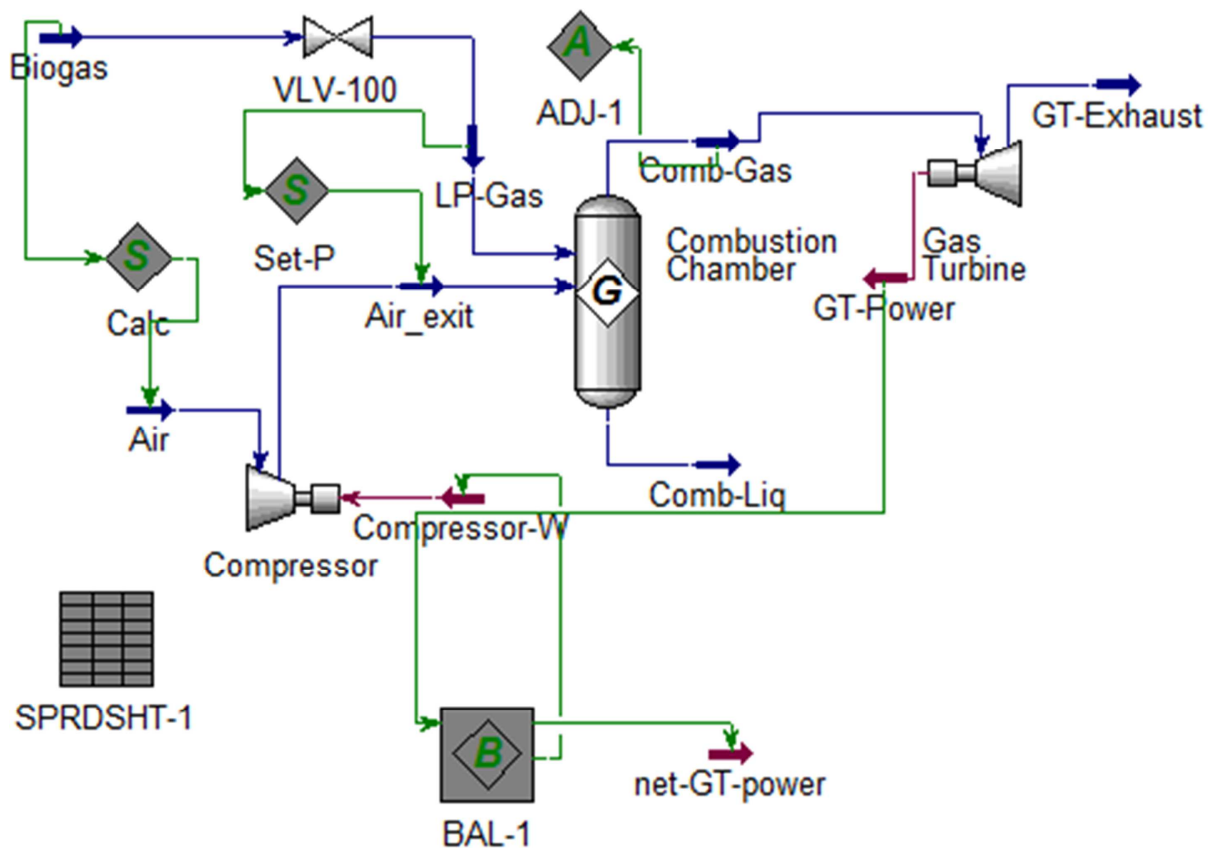

Figure 3. GT-only system configuration.

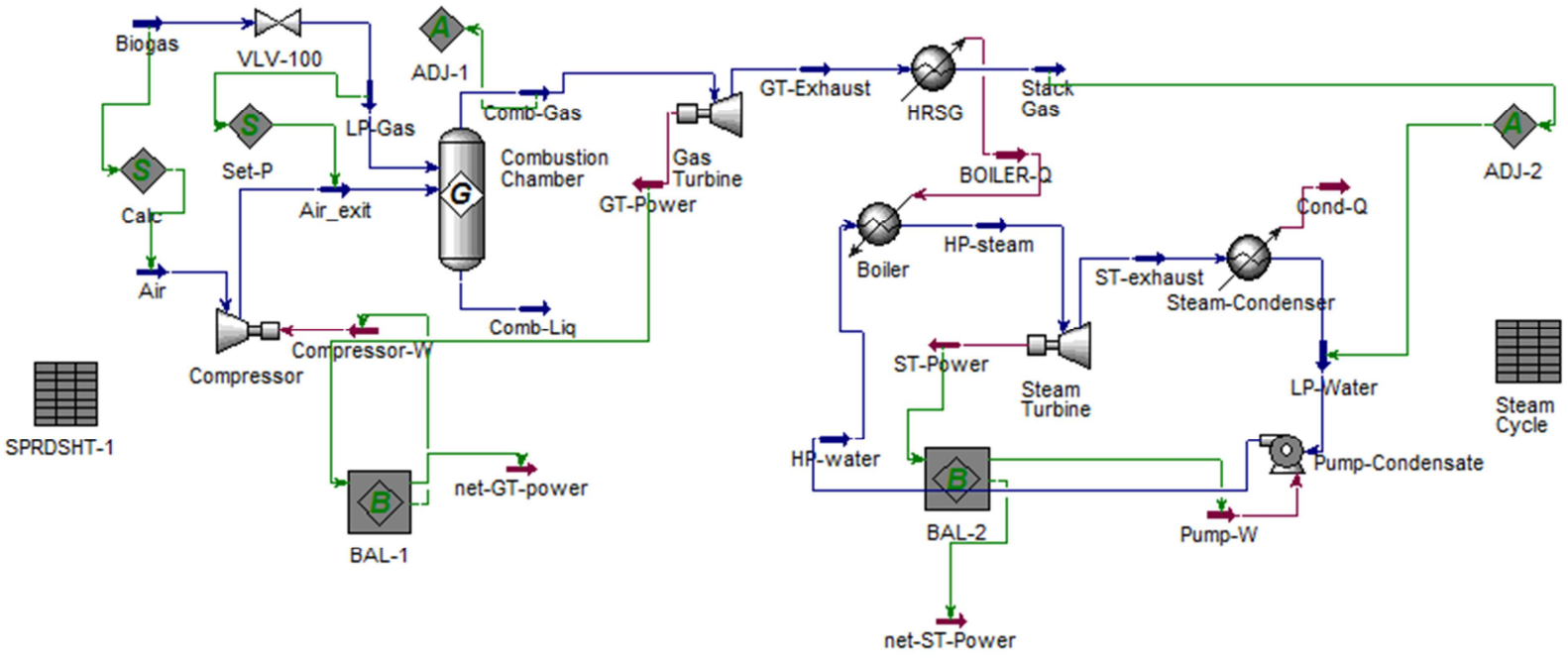

Figure 4. Combined GT-ST system configuration.

\section{Results}

The proposed utilization of biogas for power generation in this study is done basing on a target to generate at least $2.5 \mathrm{MW}$ of electricity. The simulated topping configurations were compared to the GTU-2.5P gas turbine for validation where results were in close agreement. Table 3 shows the digester need estimates to meet the minimum power generation of $2.5 \mathrm{MW}$. It should be noted that the maintained cow head count is 13740 , a count that can easily be met by the cattle-keeping culture of western Uganda communities. Material balance from the gas turbine alone (GT) system for a $71 \%$ methane-29\% carbon dioxide are that had an efficiency of $33 \%$ is given in Table 4 showing molar and mass flow rates of biogas for each component unit. Basically the flow rates of flue and exhaust gases are the same except their temperatures and pressures. This is because the flue gases have passed through a turbine and given their energy contents to generate electricity in the turbine (Table 4). Table 5 shows molar compositions of air, biogas, flue and exhaust gases for $29 \% \mathrm{CO}_{2}-71 \% \mathrm{CH}_{4}$ system. The flue gas contains $5 \% \mathrm{CO}_{2}, 13 \% \mathrm{O}_{2}, 74 \% \mathrm{~N}_{2}, 8 \% \mathrm{H}_{2} \mathrm{O}$ and negligible amount of $\mathrm{CH}_{4}$. Looking at these results, it can be concluded that these exhaust gases do not constitute environmental threats at all when disposed to the atmosphere.

Table 3. Digester need estimates.

\begin{tabular}{ll}
\hline Parameter & Estimate \\
\hline Electricity runtime (h/day) & 24 \\
Manure loading rate (kg/day) & $668,672.7$ \\
Maintained cow head count & 13740 \\
Digester volume $\left(\mathrm{m}^{3}\right)$ & 23881 \\
\hline
\end{tabular}


Table 4. Material balance for GT-alone system $71 \% \mathrm{CH} 4-29 \% \mathrm{CO}_{2}$.

\begin{tabular}{lllllll}
\hline Parameters & Biogas & LP-Gas & Air & Compressed Air & Flue Gas & GT-Exhaust \\
\hline Vapour Fraction & 1 & 1 & 1 & 1 & 1 & 1 \\
Temperature $\left({ }^{\circ} \mathrm{C}\right)$ & 25.000 & 18.195 & 25.000 & 335.186 & 1049.998 & 550.000 \\
Pressure $(\mathrm{bar})$ & 21.013 & 10.010 & 1.013 & 10.010 & 10.010 & 0.852 \\
Molar Flow $(\mathrm{kgmol} / \mathrm{h})$ & 46.370 & 46.370 & 1000.000 & 1000.000 & 1046.365 & 1046.365 \\
Mass Flow $(\mathrm{kg} / \mathrm{s})$ & 0.311 & 0.311 & 7.958 & 7.958 & 8.269 & 8.269 \\
\hline
\end{tabular}

Table 5. Molar composition of gases for GT-alone system, $71 \% \mathrm{CH}_{4}-29 \% \mathrm{CO}_{2}$.

\begin{tabular}{lllllll}
\hline Air composition & Biogas & LP-Gas & Air & Compressed Air & Flue Gas & GT-Exhaust \\
\hline Mole Frac $\left(\mathrm{CO}_{2}\right)$ & 0.29 & 0.29 & 0.0003 & 0.0003 & 0.044602 & 0.044601822 \\
Mole Frac $\left(\mathrm{O}_{2}\right)$ & 0 & 0 & 0.2059 & 0.2059 & 0.133646 & 0.133645684 \\
Mole Frac $\left(\mathrm{N}_{2}\right)$ & 0 & 0 & 0.7748 & 0.7748 & 0.74027 & 0.74026964 \\
Mole Frac $\left(\mathrm{CH}_{4}\right)$ & 0.71 & 0.71 & 0 & 0 & $4.14 \mathrm{E}-34$ & $4.14 \mathrm{E}-34$ \\
Mole Frac $\left(\mathrm{H}_{2} \mathrm{O}\right)$ & 0 & 0 & 0.019 & 0.019 & 0.081086 & 0.081085578 \\
Mole Frac $(\mathrm{NO})$ & 0 & 0 & 0 & 0 & 0.000388 & 0.000387884 \\
\hline
\end{tabular}

The net energy derived from it is $2.5 \mathrm{MW}$ which is available for use by the community. With many of such offgrid stations like this one within the cattle rearing community, the country's Rural Electrification Policy could easily be implemented in these areas. Similar occurrence happens with the combined GT-ST system for $71 \% \mathrm{CH}_{4}-$
$29 \% \mathrm{CO}_{2}$ with a better efficiency at $48 \%$ but the exhaust gas compositions remain the same Tables 6 and 7. The net energy obtained from this system is $3.55 \mathrm{MW}$ which is available for use by the community. The combined GT-ST system therefore provides a better net energy output for the same purity of $71 \% \mathrm{CH}_{4}$ and $29 \% \mathrm{CO}_{2}$, Tables 6,7 , and 8 .

Table 6. Material balance for combined system $71 \% \mathrm{CH}_{4}-29 \% \mathrm{CO}_{2}$.

\begin{tabular}{lllllllllll}
\hline Parameters & $\begin{array}{l}\text { HP- } \\
\text { water }\end{array}$ & $\begin{array}{l}\text { LP- } \\
\text { Water }\end{array}$ & $\begin{array}{l}\text { HP- } \\
\text { steam }\end{array}$ & $\begin{array}{l}\text { ST- } \\
\text { exhaust }\end{array}$ & Biogas & $\begin{array}{l}\text { LP- } \\
\text { Gas }\end{array}$ & Air & $\begin{array}{l}\text { Compressed } \\
\text { Air }\end{array}$ & Flue Gas & $\begin{array}{l}\text { GT- } \\
\text { Exhaust }\end{array}$ \\
\hline Vapour Fraction & 0 & 0 & 1 & 0.803 & 1 & 1 & 1 & 1 & 1 \\
Temperature $\left({ }^{\circ} \mathrm{C}\right)$ & 20.057 & 20.000 & 179.009 & 20.004 & 25.000 & 18.195 & 25.000 & 335.186 & 1049.998 & 550.000 \\
Pressure (bar) & 10.000 & 0.023 & 9.800 & 0.023 & 21.013 & 10.010 & 1.013 & 10.010 & 10.010 & 0.852 \\
Molar Flow (kgmol/s) & 298.007 & 298.007 & 298.007 & 298.007 & 46.370 & 46.370 & 1000.000 & 1000.000 & 1046.365 & 1046.365 \\
Mass Flow (kg/s) & 1.491 & 1.491 & 1.491 & 1.491 & 0.311 & 0.311 & 7.958 & 7.958 & 8.269 & 8.269 \\
\hline
\end{tabular}

Table 7. Combined GT-ST molar composition $71 \% \mathrm{CH}_{4}-29 \% \mathrm{CO}_{2}$.

\begin{tabular}{lllllll}
\hline Air composition & Biogas & Air & Compressed Air & Flue Gas & GT-Exhaust & Stack Gas \\
\hline Mole Frac $\left(\mathrm{CO}_{2}\right)$ & 0.29 & 0.0003 & 0.0003 & 0.044602 & 0.044601822 & 0.044602 \\
Mole Frac $\left(\mathrm{O}_{2}\right)$ & 0 & 0.2059 & 0.2059 & 0.133646 & 0.133645684 & 0.133646 \\
Mole Frac $\left(\mathrm{N}_{2}\right)$ & 0 & 0.7748 & 0.7748 & 0.74027 & 0.74026964 & 0.74027 \\
Mole Frac $\left(\mathrm{CH}_{4}\right)$ & 0.71 & 0 & 0 & $4.14 \mathrm{E}-34$ & $4.14 \mathrm{E}-34$ & $4.14 \mathrm{E}-34$ \\
Mole Frac $\left(\mathrm{H}_{2} \mathrm{O}\right)$ & 0 & 0.019 & 0.019 & 0.081086 & 0.081085578 & 0.081086 \\
Mole Frac $(\mathrm{NO})$ & 0 & 0 & 0 & 0.000388 & 0.000387884 & 0.000388 \\
\hline
\end{tabular}

Table 8. Energy flow for combined system $71 \% \mathrm{CH}_{4}-29 \% \mathrm{CO}_{2}$.

\begin{tabular}{lllllll}
\hline Energy & Pump-W & ST-Power & Comp-W & GT-Power & net-GT-power & net-ST-Power \\
\hline Heat Flow $(\mathrm{kJ} / \mathrm{s})$ & 1.753852 & 1073.405 & 2602.47 & 5075.93229 & 2473.462646 & 1071.650824 \\
\hline
\end{tabular}

The effluents that result from the production of biogas provides manure for exhausted farmlands within the community for increased crop yields.

\section{Conclusions}

A simulation of electricity generation from biogas was conducted for use in the Ugandan rural community using Aspen HYSYS V8.8. For a biogas composition of $71 \%$ methane and $29 \%$ carbon dioxide with the gas flow rate of $0.331 \mathrm{~kg} / \mathrm{s}$ for a single gas turbine (GT) system alone, the net energy obtained from the system is $2.5 \mathrm{MW}$ which is available for use by the community.

For a combined gas turbine-steam turbine (GT-ST) system, an extra 1MW can be generated for the community to give a total net of 3.5MW. This amount of energy surpasses the need for an average community with 5000 households and the excess can be sold to the national grid to supplement deficiencies. To meet the above requirements a cattle head count of 13740 needs to be maintained, a figure that can easily be met by the cattle rich communities under consideration.

\section{Acknowledgements}

We would like to appreciate the financial support from Kyambogo University Research, Grants and Publication Committee which made it possible for us to realize this work. 


\section{References}

[1] UBOS, 2016 Statistical Abstract, Kampala, Uganda: Uganda Bureau of Statistics, 2016.

[2] C. Okello, P. Stefania, F. Salvatore and B. Lorenzo, "Development of bioenergy technologies in Uganda: A review of progress," Renewable and Sustainable Energy Reviews, pp. 55-63, 2013.

[3] O. Maested, "The electricity sector of Uganda - results of development assistance," Institute for Research in Economics and Business Administration, Bergen, 2003.

[4] T. Ssennoga, A. R. Makbul, M. M. Patrick, U. M. Muhammad and K. N. Hussein, "Renewable based distributed generation in Uganda: Resource potential and status for exploitation," Renewable and Sustainable Energy Reviews, pp. 786-798, 2016.

[5] MEMD, "UGANDA'S SUSTAINABLE ENERGY FOR ALL (SE4All) INITIATIVE ACTION AGENDA," Ministry of Energy and Mineral Development, Kampala, 2015.

[6] "Access to electricity," 16 March 2017. [Online]. Available: http://data.worldbank.org/indicator/EG.ELC.ACCS.ZS?view= chart.

[7] T. Buchholz and I. Da Silva, "Potential of distributed woodbased biopower systems serving basic electricity needs in rural Uganda," Energy for Sustainable Development, pp. 5661,2010 .

[8] S. N. Mudoko, "Uganda's Policy on Energy and Power," in JICA Training on Energy Policy, Tokyo, 2013.

[9] E. H. Seyed, B. Hasan, A. W. Mazlan, G. Abdolsaeid and M. S. Mohsin, "Thermodynamic assessment of integrated biogasbased micro-power generation system," Energy Conversion and Management, pp. 104-119, 2016.

[10] Y. K. Jun, W. K. Do, S. K. Tong and B. H. Kwang, "Comparative economic analysis of gas turbine-based power generation and combined heat and power systems using biogas fuel," Energy, pp. 309-318, 2014.

[11] C. Chia-wei, L. Tsung-han, L. Wei-tsung and C. Chun-hsun, "Electricity Generation Using Biogas From Swine Manure for Farm Power Requirement," International Journal of Green Energy, pp. 339-346, 2015.

[12] C. Okello, P. Stefania, F. Salvatore and B. Lorenzo, "Bioenergy potential of agricultural and forest residues in uganda," Biomass and Bioenergy, pp. 515-525, 2013.

[13] S. Rasi, A. Veijanen and J. Rintala, "Trace compounds of biogas from different biogas production plants," Energy, pp. 1375-1380, 2007.

[14] E. H. Seyed and A. W. Mazlan, "Development of biogas combustion in combined heat and power generation," Renewable and Sustainable Energy, pp. 868-875, 2014.

[15] F. Ahmad, K. Lau, A. Shariff and G. Murshid, "Process Simulation and Optimal design of membrane separation system for $\mathrm{CO} 2$ capture from natural gas," Computers \& Chemical Engineering, pp. 119-128, 2012.

[16] M. Y. Ahmed, A. E. Yehia, M. E.-M. Wael and A. Abdelhamid, "Upgrading biogas by a low-temperature $\mathrm{CO} 2$ removal technique," Alexandria Engineering Journal, pp. 1143-1150, 2016.

[17] F. Bauer, C. Hulteberg, T. Persson and D. Tamm, "Biogas Upgrading - Review of commercial technologies," Svenskt Gastekniskt Center, 2013.

[18] R. Bove and P. Lunghi, "Electric power generation from landfill gas using traditional and innovative technologies," Energy Conversion and Management, pp. 1391-1401, 2006.

[19] H. B. Avval, P. Ahmadi, A. Ghaffarizadeh and M. Saidi, "Thermo-economic-environmental multiobjective optimization of a gas turbine power plant with preheater using evolutionary algorithm," International Journal of Energy Research, pp. 389-403, 2011.

[20] J. Bruno, V. Ortega-Lopez and A. Coronas, "Integration of absorption cooling systems into micro gas turbine trigeneration systems using biogas: Case Study of a sewage treatment plant," Applied Energy, pp. 837-847, 2009.

[21] I. A. Hilkiah, M. J. Ayotamuno, C. L. Eze, S. O. T. Ogaji and S. D. Probert, " Designs of anaerobic digesters for producing biogas from municipal solid-waste," Applied Energy, pp. 430438, 2008.

[22] J. Huang and R. J. Crookes, "Assessment of simulated biogas as a fuel for the spark ignition engine," Fuel, pp. 1793-1801, 1998.

[23] G.-L. M. T. B. Van, L. B. T. Truong and L. T. Hau, "Biogasgasoline hybrid engine," Da Nang University, 2008.

[24] E. C. Carlson, "Don't Gamble with Physical properties for simulations," Chemical Engineering Progress, pp. 35-46, 1996.

[25] W. Arini, A. Diani, S. Aep and S. Hen, "Economic Analysis of cow manure biogas as Energy source for electricity power generation in small scale ranch," in 2nd International Conference on Sustainable Energy Engineering and Application, ICSEEA 2014, Bandung, 2015.

[26] "Ankole-Watusi Cattle," [Online]. Available: watusi@aol.com. [Accessed July 2017]. 